\title{
Differential loggerhead by-catch and direct mortality due to surface longlines according to boat strata and gear type
}

\author{
JUAN A. CAMIÑAS ${ }^{1}$, JOSÉ C. BÁEZ ${ }^{1,2}$, XULIO VALEIRAS ${ }^{3}$ and RAIMUNDO REAL ${ }^{2}$ \\ ${ }^{1}$ Instituto Español de Oceanografía, Centro Oceanográfico de Málaga, Fishing Port s/n pots number 285, \\ 29640 Fuengirola, Málaga, Spain. E-mail: jacaminas@ma.ieo.es \\ ${ }^{2}$ Departamento de Biología Animal (Zoología), Facultad de Ciencias, Universidad de Málaga, Campus de Teatinos s/n, \\ E-29071 Málaga, Spain. \\ ${ }^{3}$ Instituto Español de Oceanografía, Centro Oceanográfico de Santander, Sant Martin s/n, 39004 Santander, Spain.
}

SUMMARY: Surface longline gears are used to fish different species, mainly albacore Thunnus alalunga (Bonnaterre, 1788), bluefin tuna Thunnus thynnus (Linnaeus, 1758), and swordfish Xiphias gladius Linnaeus, 1758, and are considered highly dangerous for threatened marine turtles. Loggerheads Caretta caretta (Linnaeus, 1758) can be incidentally captured by surface longlines. A number of captured individuals die during the fishing operation, which we consider direct mortality due to fishing. We analysed the relative loggerhead by-catch and direct mortality associated with each type of boat and gear from April to December during the period 1999-2004 in the Spanish surface longline fleet that fishes in the western Mediterranean Sea, an important fishing area for this fleet. We used different indices to compute the catch per unit effort (CPUE) according to the number of hooks and to the number of fishing operations for each type of boat and gear. Both bycatch and direct mortality differed significantly according to the type of boat and gear. With respect to the number of hooks, boats longer than $12 \mathrm{~m}$ not using a roller and targeting bluefin tuna captured the highest number of loggerheads, whereas boats longer than $12 \mathrm{~m}$ with a roller that targeted swordfish caused the highest direct mortality. With respect to the number of fishing operations, boats longer than $12 \mathrm{~m}$ without a roller that targeted albacore captured the highest number of loggerheads; the highest direct mortality was caused by this type of boat and by boats longer than $12 \mathrm{~m}$ using a roller and targeting swordfish.

Keywords: Caretta caretta, drifting longline, fisheries, incidental capture, pre-release mortality, sea turtle.

RESUMEN: DIFERENCIAS EN LAS CAPTURAS NO DIRIGIDAS Y MORTALIDAD DIRECTA DE TORTUGA BOBA EN PALANGRE DE SUPERFICIE DE ACUERDO AL ESTRATO DE FLOTA Y TIPO DE APAREJO. - El palangre de superficie es usado para la pesca de diferentes especies, fundamentalmente atún blanco Thunnus alalunga (Bonnaterre, 1788), atún rojo Thunnus thynnus (Linnaeus, 1758) y pez espada Xiphias gladius Linnaeus, 1758, y es considerado altamente peligroso para las tortugas marinas amenazadas. La tortuga boba Caretta caretta (Linnaeus, 1758) puede ser capturada incidentalmente por el palangre de superficie y un número considerable de ellas puede morir durante la operación de pesca, y son consideradas como muertas directamente en el palangre. En este trabajo se analizan la capturas incidentales y la mortalidad directa relativa asociada a cada tipo de barco y aparejo de pesca, desde abril a diciembre durante el periodo 1999-2004, en la flota palangrera española en el Mediterráneo occidental, una importante área de pesca para esta flota. Se usaron diferentes índices para calcular las capturas por unidad de esfuerzo (CPUE) de acuerdo al número de anzuelos y al número de operaciones de pesca para cada tipo de barco y aparejo. Tanto las capturas no dirigidas de la tortuga boba como la mortalidad directa presentan diferencias significativas en función del tipo de barco y aparejo. Con respecto al número de anzuelos, los barcos mayores de $12 \mathrm{~m}$ de eslora sin rulo y especie objetivo atún rojo presentaron el mayor número de capturas relativas de tortuga boba, mientras que los barcos mayores de $12 \mathrm{~m}$ de eslora con rulo y especie objetivo pez espada presentaron los mayores valores de mortalidad directa. En función del número de operaciones de pesca, los barcos mayores de $12 \mathrm{~m}$ de eslora sin rulo y especie objetivo atún blanco presentaron el mayor número de capturas relativas de tortuga boba, mientras que los mayores índices de mortalidad directa relativa fueron observados en éstos y en los barcos mayores de $12 \mathrm{~m}$ con rulo y especie objetivo pez espada.

Palabras clave: captura no dirigida, Caretta caretta, mortalidad directa, pesquerías, tortugas marinas, palangre de superficie. 


\section{INTRODUCTION}

Caretta caretta (Linnaeus, 1758) is included in the red list of threatened species of the IUCN (2001) (http://www.redlist.org/), and is considered to be a species of interest in the European Union and Spain (Official Journal of the European Union 1997 8.11.97/L305/50-; B.O.E. 1990 -5.4.90/9470/82-). Surface longline is considered one of the most dangerous fishing gears for threatened marine turtles (Lewison et al., 2004), and is the main threat for the marine turtle populations of the western Mediterranean Sea (Aguilar et al., 1992; Camiñas 1997; Camiñas and Valeiras, 2001). Many Mediterranean countries use this surface gear to target different species, mainly albacore Thunnus alalunga (Bonnaterre, 1788), bluefin tuna Thunnus thynnus (Linnaeus, 1758), and swordfish Xiphias gladius Linnaeus, 1758.

Loggerheads can be incidentally captured by surface longlines but information on direct mortality of this or other marine turtles is scarce (Laurent et al., 2001). As a number of loggerheads are caught dead, we consider this number as the direct pre-release mortality, and we will refer to it as direct mortality hereafter. Surface longline fishery is a very important activity for the Spanish fleet in the Mediterranean Sea (Camiñas et al., 1992), which is comprised of different boat strata that target different species by modifying the surface longline (using different lengths, baits, fishing depths, hooks and rollers) according to the season, target species abundance, market conditions and boat length (see Table 1). Since 2003 a new gear type called "american" and also "roller" has been introduced into the fleet, which implies a reduction in the number of hooks and an increase in the main line length and the depth of fishing (Báez et al., 2005). This modified surface longline increases the distance between hooks $(21 \mathrm{~m}$ in traditional long-line SWB and $90 \mathrm{~m}$ in SWBr, abbreviations as in Table 1) and the length of the gear (30-40 nautical miles in traditional long-line and 60-70 nautical miles total length in SWBr), reducing the average number of hooks to 1000 (versus $>2500$ mean number of hooks in traditional surface longline), and the time needed to board the gear to 6-7 hours, which entails a 2-3 hour reduction with respect to the traditional longline.

An onboard observer program was implemented by the IEO (Spanish Institute of Oceanography) to obtain direct information from the fisheries regarding target and incidental species. In this paper we analyse the data obtained in the above mentioned program, focusing on the comparison between loggerhead incidental by-catch and direct mortality caused by different types of boats and gears, observed from April to December during the period 1999-2004 in the Spanish surface longline fleet fishing in the western Mediterranean Sea.

\section{MATERIAL AND METHODS}

The Spanish surface longline fleet from Mediterranean ports consists of 105 vessels from 12 to $27 \mathrm{~m}$ in length licensed for surface longline fishing around the year, and more than 2000 shorter boats licensed for artisanal gears, including surface longline, fishing mainly in summer (http://www.mapya.es). The fishing grounds include a large area of the western Mediterranean between $36^{\circ}$ and $44^{\circ} \mathrm{N}$ and $02^{\circ} \mathrm{W}$ and $05^{\circ} \mathrm{E}$. The strongest fishing effort is carried out around the Balearic Islands and in the Ibiza Channel (Camiñas and de la Serna, 1995; Camiñas and Valeiras, 2001; Valeiras and Camiñas, 2003).

A total of 1546 fishing operations were observed onboard from April to December, during the years 1999 to 2004, which represent 3825292 hooks controlled directly. The number of boats with onboard observers and the total number of fishing boats each year can be seen in Table 2. We took data on effort (number of hooks), environmental data (superficial temperature of the water, distance to the coast, depth and weather conditions), standardised fishing parameters (time and spatial co-ordinates, number of attracting lights, and type and size of the bait),

TABLE 1. - Boat strata used in this paper and their respective abbreviations.

\begin{tabular}{|c|c|c|c|}
\hline Target species & $\begin{array}{l}\text { Boats }<12 \mathrm{~m} \text { in length, } \\
\text { without a "roller" }\end{array}$ & $\begin{array}{l}\text { Boats }>12 \mathrm{~m} \text { in length, } \\
\text { without a "roller" }\end{array}$ & $\begin{array}{l}\text { Boats }>12 \mathrm{~m} \text { in length, } \\
\text { with a "roller" }\end{array}$ \\
\hline Albacore & --- & ALB & --- \\
\hline Bluefin tuna & --- & $\mathrm{BFT}$ & $\mathrm{BFTr}$ \\
\hline Swordfish & SWA & SWB & SWBr \\
\hline
\end{tabular}


TABLE 2. - Number of boats with onboard observers and total number of fishing boats (in parentheses) each year according to boat strata. Abbreviations as in Table 1.

\begin{tabular}{ccccccc}
\hline Year & $\begin{array}{c}\text { BFT } \\
(105)\end{array}$ & $\begin{array}{c}\text { BFTr } \\
(<105)\end{array}$ & $\begin{array}{c}\text { SWA } \\
(>2000)\end{array}$ & $\begin{array}{c}\text { SWB } \\
(105)\end{array}$ & $\begin{array}{c}\text { SWBr } \\
(<105)\end{array}$ & $\begin{array}{c}\text { ALB } \\
(105)\end{array}$ \\
\hline 1999 & 1 & 0 & 3 & 9 & 0 & 2 \\
2000 & 6 & 0 & 3 & 9 & 0 & 1 \\
2001 & 2 & 0 & 1 & 3 & 0 & 0 \\
2002 & 4 & 0 & 0 & 4 & 0 & 0 \\
2003 & $1(<105)$ & 1 & 0 & $5(<105)$ & 1 & 0 \\
2004 & $1(<105)$ & 2 & 2 & $6(<105)$ & 2 & 0 \\
\hline
\end{tabular}

fishing strategies, and fleet dynamics (see Valeiras and Camiñas, 2003). We classified the fleet into six boat strata with some differences in structure and target species (Table 1). Sea turtle by-catch and direct mortality were recorded and classified according to gear type and boat strata.

As the catch per unit effort (CPUE) measure we used the index $\mathrm{R}$ (number of incidental catches / number of hooks ${ }^{-3}$ ), $\mathrm{R}_{\text {dead }}$ (number of direct turtle mortalities / number of hooks ${ }^{-3}$ ) (Yeung, 1998; Laurent et al., 2001; Valeiras and Camiñas, 2003; Lewison et al., 2004), F rate (number of incidental catches / number of fishing operations), and $F_{\text {dead }}$ (number of direct mortalities / number of fishing operations). We tested the inter-annual differences in $\mathrm{R}$ and $\mathrm{F}$ within boat strata and gear, and differences in $\mathrm{R}, \mathrm{R}_{\text {dead }}, \mathrm{F}$, and $\mathrm{F}_{\text {dead }}$ among boat strata and gears with data from all years pooled together, using the chi-squared $\left(\chi^{2}\right)$ test. Expected valued in the $\chi^{2}$ tests were calculated according to the number of hooks for $\mathrm{R}$ and $\mathrm{R}_{\text {dead }}$, and to the number of fishing operations for $\mathrm{F}$ and $\mathrm{F}_{\text {dead. }}$

\section{RESULTS}

The number of fishing operations observed for each boat strata, type of gear, and year, and the corresponding values of loggerhead by-catch and direct mortality can be seen in Table 3. Direct mortality is a low frequency phenomenon. We observed 3480 loggerhead incidental catches, 46 of which the turtle was dead, so the proportion of dead turtles was $1.32 \%$ of the incidental catches. Inter-annual differences in $\mathrm{R}$ and $\mathrm{F}$ were significant for every boat strata except BFTr (Table 3). These inter-year differences may be explained by variations in sea turtle concentrations in feeding areas according to the variations in environmental factors and migratory patterns. Thus, it is preferable to study all catches pooled together to mitigate the effect of inter-annual concentration differences. In addition, the low number of directly dead turtles prevents analysing $\mathrm{R}$ and $\mathrm{F}$ within a single year.

We observed direct mortality in all boat strata (Table 4), but the relative direct mortality varied among them. Both the by-catch and the direct mortality differed significantly according to the type of boat and gear but the results differed according to whether they were measured in function of the number of hooks or in function of the number of fishing operations (Table 4). With respect to the number of hooks, boats longer than $12 \mathrm{~m}$ without a roller that targeted bluefin tuna captured the highest number of Loggerheads, whereas boats longer than $12 \mathrm{~m}$ with a roller that targeted swordfish caused the highest direct mortality. With respect to the number of fish-

TABLE 3. - Number of hooks in thousands (first number) and fishing operations (second number) observed for each boat strata and year. In brackets, the number of by-catch (first number) and dead turtles (second number). The asterisks indicate significant inter-annual differences. Abbreviations as in Table 1.

\begin{tabular}{|c|c|c|c|c|c|c|}
\hline Year & BFT & $\mathrm{BFTr}$ & SWA & SWB & SWBr & ALB \\
\hline 1999 & $\begin{array}{c}14 / 14 \\
(0 / 0)\end{array}$ & $0 / 0$ & $\begin{array}{c}31.46 / 21 \\
(43 / 0)\end{array}$ & $\begin{array}{c}555.06 / 180 \\
(162 / 0)\end{array}$ & $0 / 0$ & $\begin{array}{c}280.32 / 63 \\
(293 / 4)\end{array}$ \\
\hline 2000 & $\begin{array}{c}224.5 / 148 \\
(391 / 13)\end{array}$ & $0 / 0$ & $\begin{array}{c}24.6 / 15) \\
(5 / 0)\end{array}$ & $\begin{array}{c}727.9 / 242 \\
(1,068 / 8)\end{array}$ & $0 / 0$ & $\begin{array}{c}18.65 / 7 \\
(61 / 1)\end{array}$ \\
\hline 2001 & $\begin{array}{c}54.704 / 37 \\
(286 / 0)\end{array}$ & $0 / 0$ & $\begin{array}{c}115.7 / 74 \\
(73 / 2)\end{array}$ & $\begin{array}{c}531.894 / 143 \\
(283 / 1)\end{array}$ & $0 / 0$ & $0 / 0$ \\
\hline 2002 & $\begin{array}{c}61.7 / 30 \\
(26 / 0)\end{array}$ & $0 / 0$ & $0 / 0$ & $\begin{array}{c}408.883 / 115 \\
(74 / 0)\end{array}$ & $0 / 0$ & $0 / 0$ \\
\hline 2003 & $\begin{array}{c}58.22 / 23 \\
(41 / 0)\end{array}$ & $\begin{array}{c}17.168 / 12 \\
(24 / 0)\end{array}$ & $0 / 0$ & $\begin{array}{c}219.644 / 87 \\
(246 / 1)\end{array}$ & $\begin{array}{c}77.952 / 56 \\
(14 / 0)\end{array}$ & $0 / 0$ \\
\hline 2004 & $\begin{array}{c}11.9 / 14 \\
(2 / 0)\end{array}$ & $\begin{array}{c}33.922 / 19 \\
(30 / 1)\end{array}$ & $\begin{array}{c}53.75 / 35 \\
(4 / 0)\end{array}$ & $\begin{array}{c}52.85 / 33 \\
(4 / 0)\end{array}$ & $\begin{array}{c}123.114 / 155 \\
(340 / 15)\end{array}$ & $0 / 0$ \\
\hline df & 5 & 1 & 4 & 5 & 1 & 1 \\
\hline $\mathrm{R} \chi^{2}$-value & 138.104 & 0.157 & 80.82 & 236.54 & 24.39 & 8.55 \\
\hline $\mathrm{P}$ & $<0.001 *$ & 0.9 & $<0.001 *$ & $<0.001 *$ & $<0.001 *$ & $<0.001 *$ \\
\hline F $\chi^{2}$-value & 444.79 & 0.75 & 49.096 & 846.89 & 92.62 & 20.57 \\
\hline $\mathrm{P}^{n}$ & $<0.001 *$ & 0.1 & $<0.001 *$ & $<0.001 *$ & $<0.001 *$ & $<0.001 *$ \\
\hline
\end{tabular}


TABLE 4. - Total effort, sea turtle mortality, and mortality rates for boat strata during 1999-2004. Abbreviations as in Table 1. R: number of incidental turtle catches / number of hooks (in thousands); F: number of incidental turtle catches / number of fishing operations; $\mathrm{R}_{\text {dead }}$ : number of dead turtles / number of hooks (in thousands); $\mathrm{F}_{\mathrm{dead}}$ : number of dead turtles / number of fishing operations. There are two values in each square of the $\chi^{2}$-value column, the top value is the $\chi^{2}$-value if the distribution of hooks is random, and the bottom value is the $\chi^{2}$-value if the distribution of the fishing operations is random. The numbers with two asterisks indicate the highest values.

\begin{tabular}{|c|c|c|c|c|c|c|c|c|}
\hline & BFT & $\mathrm{BFTr}$ & SWA & SWB & SWBr & ALB & $\chi^{2}$-value & $\mathrm{P}$ \\
\hline Hooks & 525.02 & 51.09 & 180.51 & 2496.181 & 261.165 & 298.970 & --- & --- \\
\hline fishing operations & 276 & 31 & 145 & 800 & 211 & 70 & --- & --- \\
\hline Sea turtle catch & 746 & 54 & 125 & 1837 & 354 & 354 & $\begin{array}{l}325.92 \\
426.79\end{array}$ & $\begin{array}{l}<0.001 \\
<0.001\end{array}$ \\
\hline Sea turtle dead & 13 & 1 & 2 & 10 & 15 & 5 & $\begin{array}{l}65.805 \\
28.0058\end{array}$ & $\begin{array}{l}<0.001 \\
<0.001\end{array}$ \\
\hline$\%$ Sea Turtle dead & 1.74 & 1.85 & 1.6 & 0.54 & 4.24 & 1.41 & --- & --- \\
\hline $\mathrm{R}$ & $1.41 * *$ & 1.057 & 0.69 & 0.74 & 1.36 & 1.18 & --- & --- \\
\hline $\mathrm{F}$ & 2.70 & 1.74 & 0.86 & 2.29 & 1.68 & $5.057 * *$ & --- & --- \\
\hline $\mathrm{R}_{\text {dead }}$ & 0.025 & 0.019 & 0.011 & 0.00401 & $0.057 * *$ & 0.017 & --- & --- \\
\hline $\mathrm{F}_{\text {dead }}^{\text {dead }}$ & 0.047 & 0.032 & 0.014 & 0.016 & $0.071 * *$ & $0.071 * *$ & --- & --- \\
\hline
\end{tabular}

ing operations, boats longer than $12 \mathrm{~m}$ without a roller that targeted albacore captured the highest number of loggerheads; the highest direct mortality was caused by this type of boat and by boats longer than $12 \mathrm{~m}$ with a roller that targeted swordfish.

\section{DISCUSSION}

There is increasing global interest in the studies of loggerhead incidental catches and mortality associated with different fisheries: driftnet (i.e. Silvani et al., 1999), gillnet (i.e. Julian and Beeson, 1998), trawls (i.e. Robins, 1995; Poiner and Harris, 1996), coastal seiner (i.e. Cheng and Cheng, 1997) and surface longline (i.e. Wetheral, 1977; Witzell, 1999; Chaloupka et al., 2004; Lewison et al., 2004). For example, several studies have focused on fishery-related loggerhead mortality in the Spanish surface drifting longline fisheries (Aguilar et al., 1992; Camiñas and de la Serna, 1995; Camiñas, 1997; Camiñas and Valeiras, 2001); however, these studies did not analyse the differences linked to the type of boat and gear.

According to recent research, the Spanish longline vessels should be classified according to the type of boat and gear (Laurent et al., 2002). Our results imply that it is necessary to study the CPUE of the different boat and gear types. The fishing effort depends not only on the number of hooks but also on other characteristics such as the use of a roller, the economic potential for buying bait and materials, the boat length, and the number of fishermen. Although the CPUE is usually calculated in function of the number of hooks (as an R-index) (Yeng, 1999; Laurent et al., 2002; Lewison et al.,
2004), we consider the $\mathrm{R}$ rate inadequate for comparing the effort of the different gear types. Table 4 shows that the results of $\mathrm{F}$ and $\mathrm{F}_{\text {dead }}$ are more consistent than those of $\mathrm{R}$ and $\mathrm{R}_{\text {dead }}$. Therefore, the $\mathrm{F}$ rate seems to be more adequate for relating the incidental catch or direct mortality to the fishing effort.

Lewison et al. (2004), estimated the number of incidental loggerhead catches in the Mediterranean surface drifting longline fishery as approximately 60000 to 80000 , but they assumed that CPUE (measured as an R-index) was homogeneous, which is not exactly so. Differences in incidental catch rates could be due to differential fishing techniques. For example, SWBr had lower $\mathrm{F}$ but higher $\mathrm{F}_{\text {dead }}$ than SWB. The main cause of direct mortality due to longlines is drowning (Work and Balazs, 2002). The "roller" gear has fewer hooks and is less time in the water, and so the number of turtle captures is decreased; however, with the deeper hooks the captured loggerheads cannot come up to the surface to breathe and therefore direct mortality is increased. These results seem to indicate that using a roller may increase Loggerhead direct mortality as it increases the probability of drowning.

Our conclusion is that in order to calculate loggerhead incidental catch or direct mortality due to surface longlines it is necessary to know the CPUE of each boat and gear type. Moreover, it is preferable to estimate the CPUE according to fishing operations. For this reason, the current database in the ICCAT (http://www.iccat.es/) should be improved by including data about boat and gear types for it to be useful for estimating the incidental catch or direct mortality in the Mediterranean due to surface longlines. 


\section{ACKNOWLEDGEMENTS}

This study was supported by three projects from the Oceanographic Centre of Malaga of the IEO (Spanish Institute of Oceanography) and financially co-supported by the European Union: Project EMTP (Assessing marine turtle by-catch in European drifting longline and trawl fisheries for identifying regulations), SWOMED (Swordfish fisheries in the Mediterranean Sea) and PALANDALIFE (Conservation of cetacean and sea turtles in Murcia and Andalucía, LIFE02NATE/8610 - Actions for reducing the impact of by-catch on the loggerhead sea turtle). We thank José Miguel de la Serna and Dr. David Macías (Oceanographic Centre of Malaga of the IEO) for providing the data from the SWOMED Project.

\section{REFERENCES}

Aguilar, R., J. Mas and X. Pastor. - 1992. Impact of Spanish swordfish longline fisheries on the loggerhead sea turtle Caretta caretta population in the western Mediterranean. In: J.I. Richardson, and T.H. Richardson (eds.), Proceedings of the $12^{\text {th }}$ annual workshop on sea turtle biology and conservation, pp. 25-29. NOAA Tech. Memo., NMFS, SEFSC 361.

Báez, J.C., J.A. Camiñas and L. Rueda. - 2006. Accidental fishing capture of marine turtles in South Spain. Mar. Turtle Newsl., 111: 11-12.

Camiñas, J.A. - 1997. Capturas accidentales de tortuga boba Caretta caretta (Linnaeus, 1758) en el Mediterráneo occidental en la pesquería de palangre de superficie de pez espada (Xiphias gladius Linnaeus, 1758). Collect. Vol. Sci. Pap. ICCAT, 4: 446-455.

Camiñas, J.A. and J.M. de la Serna. - 1995. The loggerhead distribution in the western Mediterranean Sea as deduced from captures by the Spanish longline fishery. In: G. A. Llorente, A. Montori, X. Santos and M. A. Carretero, (eds.). Sci. Herpet., 316-323.

Camiñas, J.A., J.M. de la Serna and E. Alot. - 1992. Loggerhead (Caretta caretta L.) frequency observed in the Spanish surface long-line fisheries in the western Mediterranean Sea during 1989. Rapp. Comm. Int. Mer Médit., 33: 286.

Camiñas, J.A. and X. Valeiras. - 2001. Proyecto europeo para la evaluación de las capturas accidentales de tortugas marinas en las pesquerías de palangre de superficie y arrastre en el Mediterráneo (EMPT). Primeros resultados. $1^{a}$ Simposium de la Sociedad Española de Cetáceos, Ceuta, 23-27 febrero 2000. Libro de resúmenes: 5-9.

Chaloupka, M., D. Parker and D. Balazs. - 2004. Modelling postrelease mortality of loggerhead sea turtles exposed to the Hawaii-based pelagic longline fishery. Mar. Ecol. Prog. Ser., 280: $285-293$.

Cheng, J.J. and T.H. Chen. - 1997. The incidental capture of 5 species waters of Taiwan. Biol. Conserv., 82: 235-239.

Julian, F. and M. Beenson. - 1998. Estimates of marine mammal, turtle and seabird mortality for 2 California gillnet fisheries 1990-1995. Fish. Bull., 96: 271-284.

Laurent, L., J.A. Camiñas, P. Casale, M. Deflorio, G. de Metrio, A. Kapantagakis, D. Margaritoulis, C.Y. Politou and X. Valeiras. 2001. Assessing marine turtle bycatch in European drifting longline and trawl fisheries for identifying fishing regulations. Project-EC-DG Fisheries 98-008. Joint project of BIOINSIGHT, IEO, IMBC, STPS and University of Bari. Villeurbanne, France. Available online in: http://www.seaturtle.org/).

Lewison, R.L., S.A. Freeman and L.B. Crowder. - 2004. Quantifying the effects of fisheries on threatened species: the impact of pelagic longlines on loggerhead and leatherback sea turtles. Ecol. Lett., 7: 221-231.

Poiner, J.J. and A.N.M. Harris. - 1996. The incidental capture, direct mortality and delayed mortality of turtles in Australia's northern praws fishery. Mar. Biol., 125: 813-193.

Robins, J.B. - 1995. Estimated catch and mortality of sea turtles from the east coast otter trawl fishery of Queensland, Australia. Biol. Conserv., 74: 157-167.

Silvani, L., M. Gazo and A. Aguilar. - 1999. Spanish drifnet fishing and incidental catches in the western Mediterranean. Biol. Conserv., 90: 79-85.

UICN. - 2001. Categories and criticism of the red list, of the UICN: Version 3.1. UICN, Gland, Switzerland and Cambridge, England.

Valeiras, J. and J.A Camiñas. - 2003. The incidental capture of seabirds by Spanish drifting longline fisheries in the Western Mediterranean Sea. Sci. Mar., 67(Suppl. 2): 65-68.

Wetheral, J.A. - 1977. Mortality of sea turtles in Hawaii longline fishery: a preliminary assessment of population impacts. NOAA, NMFS, SWFSC, Honolulu Laboratory, Honolulu, HI. Administrative Report H-97-07. 51 pp.

Work, T.M. and G.H. Balazs. - 2002. Necropsy findings in sea turtles taken as by-catch in the North Pacific longline fishery. Fish. Bull., 100: 876-880.

Witzell, W.N. - 1999. Distribution and relative abundance of sea turtles caught incidentally by the U.S. pelagic longline fleet in western North Atlantic Ocean, 1992-1995. Fish. Bull., 97: 200-211.

Yeung, C. - 1999. Estimates of marine mammal and marine turtle by-catch by the U.S. Atlantic pelagic longline fleet in 1998 . NOAA Tech. Memo. NMFS-SEFSC-430. 26 pp.

Received November 9, 2005. Accepted April 4, 2006.

Scient. ed.: D. Oro.

Published online November 13, 2006. 
